Biografistyka Pedagogiczna

Rok 2 (2017) nr 1

ISSN 2543-6112; e-ISSN 2543-7399

DOI: 10.36578/BP.2017.02.22

Magdalena Gajderowicz*

\title{
Listy Joanny Beretty Molli i Piotra Molli jako źródło biograficzne
}

\section{Letters by Joanna Beretta Molla and Piotr Molla as a Biographical Source}

Joanna Beretta Molla urodziła się w Magencie (prowincja Mediolanu) 4 października 1922 r. Była dziesiątym z trzynaściorga dzieci Alberto i Marii de Micheli. Rodzice przyszłej świętej należeli do Trzeciego Zakonu Świętego Franciszka. Nowonarodzona córka przyjęła sakrament chrztu świętego 11 października $1922 \mathrm{r}$. otrzymując imiona Joanna Franciszka. Z kolei 4 kwietnia 1928 r. był dniem przyjęcia przez Joannę sakramentu Pierwszej Komunii Świętej. W tym samym roku ta sześcioletnia dziewczynka rozpoczęła edukację w szkole podstawowej ${ }^{1}$.Jednak to nie szkoła, a życie w gronie najbliższych było w centrum świata tej małej dziewczynki. Rodzina Berettich słynęła ze swojej pobożności i miłości, jaką się nawzajem obdarzano. Codzienna msza święta, gra na fortepianie, podziwianie przyrody - wszystko to składało się na codzienność Joanny ${ }^{2}$. Mimo trudności w nauce, które charakteryzowały młodzieńczy etap życia, Joanna otrzymała 30 listopada 1949 r. dyplom, tym samym kończąc wymarzone studia medyczne ${ }^{3}$.

* Magdalena Gajderowicz - mgr, doktorantka w Instytucie Pedagogiki Katolickiego Uniwersytetu Lubelskiego Jana Pawła II, Katolicki Uniwersytet Lubelski, magwiniarczyk@gmail.com.

1 lipca 1912 r. w Mesero. Jego rodzice odznaczali się wyjątkową pobożnością, co skutkowało chrześcijańską formacją młodzieńca. Rodzice pokładali w Piotrze duże nadzieje, dlatego

1 P. Molla, E. Guerriero, Święta Joanna Beretta Molla, Kraków 2011, s. 143.

2 Tamże, s.2o.

3 P. Gąsior, Miłość bez lęku. Spotkania ze święta Joanną Berettą Mollą, Kraków 2004, s. 13. 
też już od najmłodszych lat dbano o jego edukację. Skutkiem tego 7 listopada 1936 r. młody Molla otrzymał dyplom inżyniera mechanika na Politechnice Mediolańskiej. Bardzo szybko, bo już 9 grudnia tego samego roku podjął pracę w zakładach Staffa, z którymi był już związany przez resztę życia4.

Przyszła święta pierwszy raz spotkała się z inżynierem Mollą w 1950 r., ale okoliczności nie sprzyjały zacieśnieniu znajomości ${ }^{5}$. Mimo iż para widywała się później kilkakrotnie w różnych sytuacjach, dopiero koniec 1954 r. okazał się przełomowy w ich życiu. Wtedy to późniejsi małżonkowie, spotykając się na przyjęciu z okazji mszy prymicyjnej kapucyna Lino Garavagilii w Uroczystość Matki Bożej Niepokalanie Poczętej, poznali się bliżej6. Relacja ta zacieśniała się dość szybko, bowiem już w kwietniu 1955 r. para zaręczyła się, a 24 września tegoż samego roku nastąpiła tak wyczekiwana przez obydwoje chwila zaślubin 7 . Owocem ich miłości są dzieci, które pojawiają się kolejno: Pierluigi w 1956 r., Mariolina w 1957, Laura w 1959 oraz 21 kwietnia 1962 r. Gianna Emanuela ${ }^{8}$. W drugim miesiącu ostatniej ciąży Joanna dowiedziała się, że choruje na włókniaka macicy. Mimo różnych propozycji leczenia, doktor Beretta Molla wybiera bezpieczną dla dziecka, ale jednocześnie ryzykowną dla siebie. Na krótko przed porodem kobieta wręcz żąda obietnicy, że jeśli nastąpi konieczność wyboru między życiem jej a dziecka, pierwszeństwo będzie miało właśnie dziecko. 28 kwietnia 1962 r., w tydzień po urodzeniu zdro-

4 J. Beretta Molla, P. Molla, Listy, red. E. Guerriero, tłum. K. Kubis, Kraków 2013, s. 32-35.

5 Piotr i Joanna pierwszy raz ujrzeli się w szpitalu. Inżynier Molla odwiedzał wtedy swoją umierającą siostrę, nad którą z kolei Joanna sprawowała opiekę lekarską.

6 P. Molla, E. Guerriero, Joanna kobieta mężna. Święta Joanna Beretta Molla we wspomnieniach męża, Kraków 2003, s. 50.

7 Tamże, s. 52.

8 P. Molla, E. Guerriero, Święta Joanna Beretta Molla, S. 145 .

9 Mój patron: święta Joanna, oprac. I. Wabik, Szczebrzeszyn 2014, s .13-14, P. Gąsior, Miłość bez lęku. Spotkania ze świętą Joanną Berettą Mollą, s.15.

10 R. Allegri, Dwie Matki Jana Pawła II. Emilia Wojtyłowa i św. Joanna Beretta Molla, Kraków 2014, s. 74.

11 J. Beretta Molla, P. Molla, Listy, s. 335-339. wej córeczki, Joanna umarła w swoim domu w Ponte Nuovo9. Renzo Allegri w swojej książce Dwie Matki Jana Pawła II, ostatni etap życia świętej opisuje w sposób następujący: „To była jej kalwaria. Najcięższa próba, do jakiej wezwał ją Bóg. Kielich z ogrodu oliwnego"10. Od tej pory to na Piotrze spoczywał obowiązek wychowania dzieci. Inżynier Molla mężnie stawia czoło wszystkim trudom życia codziennego, będąc jednocześnie obserwatorem i uczestnikiem drogi beatyfikacyjnej i kanonizacyjnej swojej żony. Umarł 3 kwietnia 2010 r. w swoim domu w Mesero, dożywszy niemal 98 lat $^{11}$. 
Celem niniejszej pracy jest przybliżenie i charakterystyka listów Joanny i Piotra, jakie małżonkowie wymieniali zarówno jeszcze przed ślubem, jak i po nim oraz wskazanie ich jako ciekawego i inspirującego źródła biograficznego. W niniejszej pracy zostały wykorzystane fragmenty owej korespondencji. Wszystkie cytaty pochodzą z polskiego wydania Listów ${ }^{12}$.

\section{Listy}

Korespondencja Joanny i Piotra powstawała od 12 stycznia 1955 do 13 grudnia 1961 r. i była efektem charakterystycznej pracy Piotra. Inżynier Molla, jako dyrektor generalny zakładów Staffa, czyli Fabryki Zapałek i Artykułów Pokrewnych mieszczącej się w Ponte Nuovo ${ }^{13}$, musiał dużo podróżować, przez co zakochani nie mogli spędzać ze sobą tyle czasu, ile by pragnęli. Aby być ze sobą w łączności, pisali listy przepełnione miłością. Na całość korespondencji składają się: siedemdziesiąt trzy listy, dziewięć pocztówek, jedenaście bilecików ${ }^{14}$, które wysłał do żony Piotr Molla oraz siedemdziesiąt trzy listy napisane ręką Świętej, których odbiorcą był jej mąż ${ }^{15}$. Biorąc pod uwagę kryterium, jakim jest czas powstawania listów, to najogólniej rzecz ujmując, tę nietypową korespondencję można podzielić na dwa etapy: z okresu narzeczeńskiego oraz małżeńskiego. Podział ten można jeszcze uszczegółowić i listy powstałe, kiedy Piotr i Joanna byli już w związku sakramentalnym, można podzielić następująco: korespondencja z pierwszych czterech lat małżeństwa, następnie listy powstałe podczas dwumiesięcznej podróży Piotra do Stanów, a także te, które powstały już po powrocie Piotra, aż do śmierci świętej. Wyżej opisany podział jest zresztą uwzględniony w polskim przekładzie korespondencji małżonków. Poniżej pragnę scharakteryzować każdy z wymienionych okresów, ponieważ w istocie listy z poszczególnych etapów różnią się od siebie.

\section{Listy z okresu narzeczeństwa}

Korespondencja z tego okresu trwała od 12 stycznia do 23 września $1955 \mathrm{r}$. Ostatni list został napisany na dzień przed ślubem narzeczonych. Całość składa się z trzynastu listów autorstwa Joanny i szesnastu Piotra.
12 Zob. przypis 4.

13 J. Beretta Molla, P. Molla, Listy, s. 36.

14 Tamże, s. 17.

15 Tamże, s. 55, jest to liczba łączna. W dalszej części artykułu liczba ta jest nieco zwiększona, gdyż listy wysyłane razem bądź też dopiski zostały potraktowane jako odrębne. 
Cechą charakterystyczną tej korespondencji jest to, iż ukazuje ona, jak pięknie rozwijało się uczucie dwojga tak bliskich sobie ludzi. Początkowy, pełen uprzejmości, ale jednak dystans, przeradza się w czułość, tęsknotę i pragnienie bycia ze sobą zakochanych. Poniższe przykłady obrazują tę przemianę.

Szanowna Pani Doktor! Nieustanny szereg wizyt, spotkań, a także przyjęć z niekończącymi się, przydługimi nordyckimi ceremoniałami pozostawiały mi niewiele godzin na sen i tak oto minął czas aż do dzisiejszego wieczora, a ja nie mogłem raz jeszcze złożyć Pani jak najszczerszego i należnego Jej podziękowania za piękny i przemiły wieczór, jaki razem spędziliśmy ${ }^{16}$.

Powyżej zacytowany fragment pochodzi z pierwszego listu inżyniera Molli do przyszłej małżonki. Nieskrywana sympatia w kierunku Joanny owiana jest formalną uprzejmością, która najprawdopodobniej wynikała z opanowanego charakteru Piotra. To właśnie Joanna, jako kobieta niezwykle ciepła i otwarta, przełamuje ten formalizm już w następnym liście, pisząc:

Najdroższy Piotrze! Wybacz, że zdecydowanie zaczynam mój list, nazywając Cię po imieniu i zwracając się do Ciebie na ty. Po wczorajszym spotkaniu, w czasie którego otworzyliśmy się wobec siebie wzajemnie, myślę, że możemy przejść na ten stopień zażyłości, która pozwoli nam lepiej się zrozumieć i pokochać ${ }^{17}$.

Entuzjazm, który ogarnia Joannę w wyniku rozwoju znajomości z Piotrem, jest nie do ukrycia. W korespondencji wybrzmiewa on w zasadzie z każdego listu. Istotne jest, że już na samym początku przyszła Święta jawi się jako kobieta, która pragnie przede wszystkim ofiarować siebie i, zgodnie z chrześcijańskim ujęciem małżeństwa, złożyć z siebie dar przyszłemu małżonkowi. Echa tej postawy również odbijają się w listach, bowiem Joanna pisze:

Chciałabym Cię po prostu uszczęśliwić i być taka, jaką mnie pragniesz: dobra, wyrozumiała i gotowa do poświeceń, których życie od nas zażąda ${ }^{18}$.

Dzięki postawie Joanny Piotr również otwiera się na to uczucie i już w bardzo szybkim czasie jego listy emanują podobną czułością.

16 List Piotra do Joanny, 12 stycznia 1955.

17 List Joanny do Piotra, 21 lutego 1955.

18 Tamże.
Moja najdroższa Joanno! Czytałem Twój list wielokrotnie i całowałem go. Zaczyna się dla mnie nowe życie: życie Twojej wielkiej i uprag- 
nionej miłości i Twej świetlanej dobroci. Rozpocznijmy życie naszej miłości. Kocham Cię, moja najdroższa Joanno ${ }^{19}$.

Ta przemiana Piotra jest odpowiedzią na gorące uczucie Joanny. W swoich listach zapewnia on nie tylko o swojej miłości, ale także, mówiąc o „nowym życiu", snuje plany na wspólną przyszłość. Okres narzeczeński, o którym obecnie mowa, obfituje w listach w podobne treści pojawiające się zarówno u Joanny, jak i jej narzeczonego. Nie są to jednak bynajmniej jedyne tematy poruszane przez nich. Dużo miejsca w korespondencji poświęcają oni Bogu oraz Matce Najświętszej. Często jest podkreślane przywiązanie do wiary obojga narzeczonych, a także powierzenie się Maryi Pannie.

Większą i bardziej upragnioną łaską nie mogła mnie obdarzyć niebieska Matka, Madonna Dobrej Rady czczona pobożnie w moim kościółku w Ponte Nuovo ${ }^{20}$.

Joanna jawi się Piotrowi jako dar Niebios. Jest on wdzięczny Maryi za relację między nim a ukochaną. Nie inaczej zresztą na ten niezwykły związek patrzy Joanna. Jej miłość, podobnie jak i Piotra, jest głęboko zakorzeniona w miłości Bożej. To wiara w Chrystusa wyznacza Joannie kierunek w drodze małżeńskiej, która naznaczona jest cierpliwością, poświęceniem i ofiarnością. Potwierdzenie powyższych refleksji znajduje się w liście z dnia 14 marca 1955 r., kiedy to Joanna pisze w sposób następujący:

[...] choć tak ogromnie pragnę Cię uszczęśliwić, obawiam się, że nie zdołam. Wówczas tak się modlę do Pana: Panie, Ty który widzisz moje uczucia i moją dobrą wolę, zaradź temu i pomóż mi stać się żoną i matką, jakiej Ty chcesz i myślę, że jakiej także Piotr pragnie ${ }^{21}$.

Pobożność z okresu narzeczeństwa, której dowody płyną niemalże z każdego listu wymienionego między Joanną a Piotrem, jest niezwykle inspirująca. Warto zwrócić uwagę na fakt, iż obydwoje starają się ukształtować i zakorzenić w Bogu swoje przyszłe małżeństwo. Świadczy to o niezwykłej dojrzałości duchowej obojga.

Wydawać by się mogło, że ten pełen miłości związek nie miał żadnych problemów. Jest to rzecz jasna założenie błędne, gdyż Piotr i Joanna, chociaż

19 List Piotra do Joanny, 22 lutego 1955.

20 Tamże.

21 List Joanny do Piotra, 14 marca. 
byli osobami niezwykłymi, to doświadczali trudności, jak każdy. Na przykład sytuacją problemową okazały się początkowe relacje przyszłej świętej z matką Piotra. Joanna na podstawie niektórych wypowiedzi późniejszej teściowej, wysnuła wniosek, iż nie jest uważana za dość dobrą kandydatkę na żonę dla inżyniera Molli22 ${ }^{22}$ Problem ten jednak dość szybko został zażegnany, a późniejsze relacje obydwu kobiet jawią się w korespondencji małżonków jako pełne szacunku i życzliwości. Sytuacja ta bynajmniej nie jest nieodpowiednią czy wstydliwą. Wręcz przeciwnie, dzięki temu, że wybrzmiała ona w omawianej korespondencji, dowiadujemy się, że problemy są udziałem wszystkich, nawet tych wyniesionych na ołtarze. Ponadto Joanna znów jawi się jako wzór, gdyż nawet w obliczu nieprzychylnych dla siebie uwag, potrafiła zachować się z klasą, okazując szacunek matce Piotra.

Omawiany okres korespondencji charakteryzuje się także pięknym motywem snucia wspólnej przyszłości. Jest to rzecz jak najbardziej naturalna, trudno bowiem wyobrazić sobie sytuację, w której przyszli małżonkowie nie marzą o wspólnym życiu. Ponownie z listów tych dwojga przebija się niezwykła czułość i romantyczność, a także tęsknota do bycia ze sobą razem, już w pełni.

Pomyśl, Piotrze, o naszym gniazdku ogrzewanym naszym uczuciem i rozweselanym przez prześliczne bajtle, które Pan nam ześle. To prawda, że przyjdą cierpienia, ale jeśli będziemy się zawsze kochać, tak jak teraz, z Bożą pomocą będziemy je umieli razem znieść ${ }^{3}$.

Najogólniej rzecz ujmując, czas przedślubny w korespondencji późniejszych państwa Mollów przedstawia się jako czas poznawania i dojrzewania do przysięgi małżeńskiej. Joanna i Piotr umacniają się nawzajem w wierze, co mocno zakorzenia ich związek w Bogu oraz Maryi. Snują plany i marzenia dotyczące ich przyszłości oraz ramię w ramię pokonują, nieliczne, ale jednak pojawiające się trudności.

\section{Listy z początkowego okresu małżeństwa}

24 września 1955 r. Piotr i Joanna przystępują do tak niecierpliwie wyczekiwanego sakramentu małżeństwa. Od tego dnia rozpoczyna się ich wspólna droga. Inży-

22 Listy Joanny do Piotra, 18 kwietnia i 10 czerwca 1955; list Piotra do Joanny, 20 kwietnia 1955.

23 List Joanny do Piotra, 5 lipca 1955. nier Molla w wyniku pełnionych obowiązków musi wielokrotnie wyjeżdżać służbowo. Chwile rozstania są dla mał- 
żonków trudne, niemniej są one wpisane w ich codzienność przez cały okres małżeństwa. Listy z tego okresu pisane są od 4 października 1955 r. do 20 lutego 1959 r. Na całość korespondencji składa się 45 listów i bilecików Piotra oraz 26 Joanny. W tym czasie miłość młodych małżonków pogłębia się i umacnia.

Mój Piotrze, jestem bardzo szczęśliwa, ponieważ Cię kocham i Ty też mnie kochasz i zrobię wszystko, abyś miał we mnie dobrą, kochającą, wyrozumiałą i zawsze uśmiechniętą żonkę ${ }^{24}$.

Postawa Joanny z okresu narzeczeństwa, kiedy jako pełna radości kobieta ciągle stawiała sobie pytanie o to, jak uszczęśliwić przyszłego męża, pozostaje aktualną także po ślubie. Joanna dalej pragnie ofiarowywać swoją miłość ukochanemu mężowi. Piotr nie pozostaje dłużny i na wyznania żony odpowiada równie romantycznymi wezwaniami.

Wyglądam z mojego okna - wychodzącego na wschód - i poza śniegiem i taflą jeziora, poza ciemnością, myślę o Tobie, która teraz słodko śpisz po tym, jak długo modliłaś się za mnie, życząc mi wszelkiego dobra. Śpij dobrze, mój skarbie! ${ }^{25}$

Istotnym jest fakt, iż małżonkowie dalej trwają i rozwijają się w wierze. Ich młode jeszcze małżeństwo, podobnie jak okres narzeczeński, obfituje we wzajemną modlitwę i rozbudowywanie relacji z Bogiem.

19 listopada 1956 r. rodzi się ich pierworodny syn, Pierluigi, a 11 grudnia 1957 r. Maria Zita, zwana później Marioliną ${ }^{26}$. Rzeczą oczywistą jest, że echa tych narodzin odbijają się także w listach małżonków. Małżonkowie wymieniają się refleksami oraz uwagami związanymi z nowonarodzonymi dziećmi.

Tutaj dzisiaj jest zimny wiatr i zamieć i Pierluigi nie może wyjść na dwór. Wyżywa się więc w domu: słucha płyt i tańczy. Wczoraj, jak Ci już mówiłam, nie wymiotował. Dziś w południe, niestety, tak, ale ma żywsze kolory i buźkę bardziej wypoczętą. Miejmy nadzieję, że były to dolegliwości związane z wyrzynaniem się ząbków ${ }^{27}$.

Aspektem niezwykle poruszającym, jest to, że święta i jej mąż przeżywała podobne problemy do wszystkich matek i ojców, kroczących drogą
24 List Joanny do Piotra, 13 grudnia 1955.

25 List Piotra do Joanny, 17 grudnia 1955.

26 P. Molla, E. Guarriero, Święta Joanna Beretta Molla, S. 145.

27 List Joanny do Piotra, 18 lutego 1958. 
małżeńską i rodzicielską. To z listów właśnie dowiadujemy się, że małżonkowie stykali się z trudnościami, w których - jeśli nie mogli być razem - wspierali się na drodze korespondencyjnej. 20 lutego 1958 r. Joanna pisze do męża w sposób żartobliwy:

Teraz jestem spokojniejsza i z Bożą pomocą, a także mobilizując całą moją dobrą wolę, spróbuję mieć bardzo dużo cierpliwości i ... poczekać, aż bajtle trochę podrosną ${ }^{28}$.

Początkowy okres małżeństwa obfituje w rozwój tej pięknej miłości. Piotr i Joanna trwają w swoich narzeczeńskich postanowieniach, dzięki czemu ich związek charakteryzuje się czułością, serdecznością i zrozumieniem. Proza życia dotyka wszystkich, jak się okazuje, także świętych. Joanna dzieli się codziennymi problemami ze swoim mężem, a on ją dzielnie w tych trudnościach wspiera.

\section{Listy z wyjazdu służbowego do Stanów Zjednoczonych}

Od 26 kwietnia do 16 czerwca 1959 r. Piotr przebywał w Stanach Zjednoczonych na służbowym wyjeździe. Może dziwić, że tak krótki, bo niespełna dwumiesięczny czas na tle kilku lat małżeństwa jest wyróżniony, jako odrębny. Należy jednak pamiętać, że okres ten obfitował w bardzo dużą ilość listów, bowiem Joanna napisała ich 31, a Piotr 34. Jest to efekt niezwykłej tęsknoty, będącej udziałem dwojga.

Podobnie jak w początkowej korespondencji małżonków i w tym okresie w listach pojawiają się liczne wyznania miłosne.

Piotrze najdroższy, nie wiem, jak Ci dziękować za wspaniałe i pełne czułości listy, które w swojej dobroci wysyłałeś do mnie codziennie. To listy wyrażające całą Twą miłość do mnie i do Twoich najdroższych skarbów, słowa odzwierciedlające Twój dobry i łagodny charakter, Twoje ogromne serce, Twoją wiarę, Twojego ducha modlitwy. Dziękuję, z serca dziękuję za wszystko. W oczekiwaniu by móc Cię uściskać, całuję Cię z ogromną miłością ${ }^{29}$.

28 List Joanny do Piotra, 20 lutego 1958.

29 List Joanny do Piotra, 8 czerwca 1959.
I chociaż uczucie małżonków nie słabnie, a wręcz przeciwnie zdaje się potęgować, to w oma- 
wianym okresie odnajdziemy zdecydowanie więcej wątków rodzicielskich i dotyczących organizacji życia rodzinnego niż w poprzednim. Joanna, która została sama, dzielnie pełniła rolę matki i gospodyni. Niemniej pragnęła dzielić swoje trudy i radości wraz z Piotrem, co też systematycznie czyniła. W jednym z listów, Święta tak opisywała chorobę syna:

W sobotę miał wysoką gorączkę, zapach acetonu z ust, ale szybko mu przeszło. W niedzielę rano był już rześki i żywiutki jak zwykle ${ }^{30}$.

Piotr, na tyle, ile mógł starał się wspierać żonę. Ponieważ z powodu odległości jego możliwości były wyjątkowo ograniczone, to pomoc ta miała wymiar duchowy:

Prosiłem Madonnę, aby należycie podziękowała Jezusowi ode mnie za nieskończony dar, jaki zrobił mi w ciągu tych lat, w postaci Ciebie, Pierluigiego, Marioliny i istotki, na którą czekamy z taką słodką niecierpliwością. Rozłąka sprawia, że tym bardziej doceniam te dary ${ }^{31}$.

Oprócz spraw związanych z opieką nad dziećmi, Joanna bardzo często powierza Piotrowi sprawy dotyczące funkcjonowania domu oraz finansów. Święta mierzy się z problemami dnia codziennego, np. zepsuta pralka ${ }^{32}$, wymiana materacy w łóżkach, cieknący bojler ${ }^{33}$, czy zepsuty gramofon ${ }^{34}$. Wszystko to owiane było niesamowitą tęsknotą, do której przyznawali się w korespondencji obydwoje. Joanna miała nawet chwile kryzysu, które opisuje w sposób następujący:

Jestem w Twoim słodkim i kochanym towarzystwie, dziś nieco podniesiona na duchu... ale wczoraj, nie mogę zaprzeczyć, byłam trochę podłamana. Chciałam Cię mieć blisko siebie, tak bardzo za Tobą tęskniłam i postanowiłam napisać do Ciebie, żebyś natychmiast wracał. Potem jednak... przeszło mi. Dziś Ci mówię: wracaj jak najszybciej, Piotruńku złoty, kiedy tylko będziesz mógł ${ }^{35}$.

Ta tęsknota, chociaż pojawia się także w innych listach, w tym okresie ma wymiar szczególny. Wynika to z faktu, iż małżonkowie nigdy nie rozstawiali się na tak długo, oraz z tego, że odległość ich dzieląca, nigdy nie była aż tak wielka. Dystans ten był przyczyną również innego wątku pojawiającego się w listach zakochanych. Otóż inżynier Molla starał się nie podróżować

30 Tamże.

31 List Piotra do Joanny, 4 maja 1959.

32 List Joanny do Piotra, 8 maja 1959.

33 List Joanny do Piotra, 19 maja 1959.

34 List Joanny do Piotra, 9 lipca 1958.

35 List Joanny do Piotra, 24 maja 1959. 
samolotem, gdyż ten środek transportu wywoływał wyjątkowy lęk u małżonki. Niestety, w czasie pobytu służbowego w Stanach Zjednoczonych latanie było nieuniknione. Fakt ten wywoływał wielkie obawy w Joannie, co oczywiście jest wyrażone w korespondencji.

Towarzyszę zawsze myślami Tobie i Twoim lotom. To się zdarza ciągle: prawie codziennie czyta się w gazetach o katastrofach samolotów. Ja już nic nie mówię, tylko się modlę i mam ufność w Panu ${ }^{36}$.

Jeśli można wskazać na istotne zmiany, które pojawiły się w korespondencji małżonków na tym etapie, to należy z pewnością zwrócić uwagę na fakt, iż Joanna i Piotr wymieniali dużo więcej informacji na temat dzieci oraz spraw organizacyjnych, co było rzecz jasna naturalnym etapem w ich życiu. Nie zmienia to jednak faktu, że ciągle motywem przewodnim jest gorące uczucie łączące małżonków, ich tęsknota, oraz odniesienia do relacji z Bogiem.

\section{Listy $\mathrm{z}$ ostatnich lat małżeńskich}

Pierwszy list z tego okresu przypada na dzień 14 grudnia 1959 r., natomiast ostatni datowany jest 13 grudnia 1961 r., czyli na nieco ponad cztery miesiące przed śmiercią świętej. Powstało wtedy 28 listów pisanych ręką Piotra i tylko 9, które wyszły spod pióra Joanny. Warto zwrócić uwagę na dużą dysproporcję, jaka zachodzi pomiędzy tą ilością, a tą figurującą w poprzednim okresie. Wynika to $\mathrm{z}$ faktu, iż małżonkowie nie przeżyli już tak długiej rozłąki, jak w omawianym poprzednio okresie. W listach tych niezmiennie dominuje tematyka miłości i tęsknoty. Już w pierwszym z nich Piotr pisze do Joanny oraz dzieci:

Nie minęła doba od przeserdecznego i jakże wzruszającego pożegnania z moją najukochańszą żoneczką i z naszymi prześlicznymi skarbami, a już czuję żywą tęsknotę i ból rozłąki ${ }^{37}$.

Oczywistym jest również fakt, że w listach małżonków ponownie wymieniane są uwagi o dzieciach. Joanna zdaje relacje ze wspólnych zabaw i sposobu spędzania dnia. Dzieli się również uwagami o zdrowiu. Jednakże listy powstałe w tym okresie charakteryzują się jeszcze innym

36 List Joanny do Piotra, 7 czerwca 1959.

37 List Piotra do Joanny, 14 grudnia 1959. istotnym aspektem. Otóż informują o nastrojach małżonków w obliczu ciężkiego stanu zdro- 
wia świętej. W momencie kiedy pisane są ostatnie listy, Joanna już wiedziała o zagrożeniu, które niesie za sobą utrzymanie ciąży. Jednakże jej postawa była niezłomna. Postanowiła za wszelką cenę chronić rozwijające się pod jej sercem życie, nawet za cenę własnego. Z listów tych można z pewnością wyczytać zaniepokojenie, ale i nadzieję jakie były udziałem Piotra:

Wiem, że w cierpieniu jesteś dzielną kobietą i umiesz ukrywać swoje troski. Wiem, że wolałabyś i pragnęła, abym się o Ciebie nie martwil. Ale prawie zawsze opanowuje mnie niepokój. Bądź nadal tak pogodna, najdroższa Joanno, a zobaczysz, że także czwarty raz macierzyństwo będzie błogosławione i radosne jak dotąd bywało ${ }^{38}$.

Pomimo ogromnej nadziei na szczęśliwe rozwiązanie sprawy, Joanna umiera 28 kwietnia 1962 r., zaledwie tydzień po narodzinach swojego czwartego dziecka Gianny Emmanueli.

\section{Zakończenie}

Joanna i Piotr niewątpliwie stanowią wzór małżeństwa. Ich relacja przepełniona była niesamowitą miłością, czułością, oddaniem, ale także tęsknotą i prozą życia codziennego. Pozostawione listy stanowić mogą niezwykłą inspirację zarówno do refleksji osobistej, jak i naukowej. Są one bowiem skarbnicą wiedzy o życiu codziennym małżonków ${ }^{39}$, ich poglądach, troskach i radościach. Z materiału źródłowego jaki tworzą, można wyczytać jakie obierali oni cele wychowawcze, co stanowiło podstawę ich moralności i wiele innych. Elio Guerriero we wstępie do Listów pisze o tej niezwykłej korespondencji w sposób następujący:

Wymiana listów między św. Joanną Berettąi jej mężem Piotrem Mollą otwiera nowy znaczący rozdział w chrześcijańskiej duchowości. Lepiej niż teologiczny traktat listy te przekonująco dowodzą, że droga świętości nie przechodzi tylko przez życie zakonne czy posługę kapłańską [... $]^{40}$.

Miłość Piotra i Joanny w istocie stanowi nieoceniony wzór życia małżeńskiego. Dzięki omawianej

38 List Piotra do Joanny, 13 grudnia 1961.

39 M. Gajderowicz, Świętość w codzienności. Joanna Beretta Molla, jako przykład godny naśladowania, w: Człowiek w świecie wartości i zagrożeń. Wybrane zagadnienia XX i XXI wieku, red. K. Sigda, R. Matusiak, K. Kozioł, Lublin 2016.

40 E. Guerriero, Wstęp. Potężniejsza niż śmierć jest miłość, w: J. Beretta Molla, P. Molla, Listy, s. 21. 
korespondencji mamy wgląd w bardzo osobiste przeżycia pary, co stanowi bardzo ciekawy materiał do podjęcia badań biograficznych nad życiem państwa Mollów. Ponadto warto zwrócić oczy ku omawianym źródłom, gdyż zdaje się, że współczesność charakteryzująca się niejednokrotnie szeroko rozumianym utylitaryzmem, właśnie takich wzorów bardzo potrzebuje.

\section{Bibliografia}

\section{Źródła}

Joanna Beretta Molla, Molla P., Listy, red. E. Guerriero, tłum. K. Kubis, Kraków 2013.

\section{Literatura przedmiotu}

Allegri R., Dwie Matki Jana Pawła II. Emilia Wojtyłowa i św. Joanna Beretta Molla, tłum. A. Zielińska, Kraków 2014.

Gajderowicz M., Świętość w codzienności. Joanna Beretta Molla, jako przykład godny naśladowania, w: Człowiek w świecie wartości i zagrożeń. Wybrane zagadnienia XX i XXI wieku, red. K. Sigda, R. Matusiak, K. Kozioł, Lublin 2016. Gąsior P., Miłość bez lęku. Spotkania ze świętą Joanną Berettą Mollą, Kraków 2004, S. 13.

Guerriero E., Wstęp. Potężniejsza niż śmierć jest miłość, w: Joanna Beretta Molla i P. Molla, Listy, red. E. Guerriero, tłum. K. Kubis, Kraków 2013.

Molla P., Guerriero E., Joanna kobieta mężna. Święta Joanna Beretta Molla we wspomnieniach męża, tłum. P. Gąsior, Kraków 2003.

Molla P., Guarriero E., Święta Joanna Beretta Molla, tłum. M. Myczkowski, Kraków 2011.

Mój patron: święta Joanna, oprac. I. Wabik, Szczebrzeszyn 2014. 